\title{
NYLON CLAMPS FOR ORCHIECTOMY HEMOSTASIS IN SWINES
}

\section{USO DA BRAÇADEIRA DE NÁILON COMO FORMA DE HEMOSTASIA EM ORQUIECTOMIAS EM SUÍNOS}

\author{
Tales Dias do Prado ${ }^{*}$ \\ Cacio Divino Alves da Costa ${ }^{1}$ \\ Anaíza Simão Zucatto do Amaral ${ }^{1}$ \\ Tiago Luís Eilers Treichel ${ }^{1}$ \\ ${ }^{1}$ Universidade de Rio Verde, Rio Verde, GO, Brazil. \\ *Corresponding author - talesprado@yahoo.com.br
}

\begin{abstract}
Orchiectomy is often employed in zootechnical activities with the main objective of carcass improvement; therefore, the search for alternatives that minimize surgical trauma, operative time and mainly decrease operating costs is pertinent. The nylon clamp is a tensile strength device, well tolerated by the body and inexpensive. It has been used as a hemostatic method in several surgical procedures. The aim of this study was to evaluate the operability and functionality of this device for the preliminary hemostasis of the spermatic cord in the open orchiectomy, comparing it to the surgical nylon thread. Twenty male pigs were divided into 2 experimental groups: GI (clamp - 10 animals) and GII (surgical nylon thread - 10 animals). The surgical time, the degree of hemostasis, the size of the incision, the presence or absence of edema and secretions, besides the weight gain were evaluated. For analysis of inflammatory response, fibrinogen was assessed. Compared to surgical nylon, the clamps presented advantages over surgical time and blood loss. It was concluded that the use of nylon clamps for hemostasis of the spermatic cords of pigs submitted to orchiectomies reduced the total time of surgeries, as well as hemorrhages, when compared to hemostasis with nylon thread. Furthermore, weight gain and induction of inflammatory response were not influenced by the hemostasis method used.
\end{abstract}

Keywords: castration; pigs; polyamide device.

\section{Resumo}

A orquiectomia é frequentemente empregada nas atividades zootécnicas com o objetivo principal de melhoria da carcaça; portanto, a busca de alternativas que minimizem o trauma cirúrgico, o tempo operatório e principalmente diminuir os custos operacionais é pertinente. A braçadeira de náilon é um dispositivo resistente à tração, bem tolerado pelo organismo e de baixo custo e tem sido utilizado como método hemostático em diversos procedimentos cirúrgicos. Objetivou-se avaliar em suínos, a operacionalidade e funcionalidade deste dispositivo para hemostasia prévia do cordão espermático na orquiectomia aberta comparando-a ao fio de náilon cirúrgico. Foram utilizados 20 suínos machos, divididos em 2 grupos experimentais: GI (braçadeira - 10 animais) e GII (fio de náilon cirúrgico 10 animais). Avaliou-se o tempo cirúrgico, o grau de hemostasia, o tamanho da incisão, a presença 
ou não de edema, o ganho de peso e se houve secreção ou não. Para análise da resposta inflamatória, a quantificação do fibrinogênio. As braçadeiras mostraram-se de fácil e rápida aplicação, conferindo a constrição necessária para a estase sanguínea e obliteração do cordão espermático de suínos. Comparada ao náilon cirúrgico, as braçadeiras apresentaram vantagens relativas ao tempo cirúrgico e à perda sanguínea. Concluiu-se que a utilização de braçadeiras de náilon para hemostasia dos cordões espermáticos de suínos submetidos à orquiectomias reduziu o tempo total das cirurgias, assim como hemorragias, quando comparada à hemostasia com fio de náilon. Além disso, o ganho de peso e a indução de resposta inflamatória não foram influenciados pelo método de hemostasia utilizado.

Palavras-chave: abraçadeira; castração; porcos.

Received on: March 6th 2017.

Accepted on: May 8th 2018.

\section{Introduction}

Surgical castration of male piglets is usually performed in most countries worldwide. It eliminates the risk of boar taint in pork meat. Surgical castration by the farmer without the use of anesthesia is still the predominant practice in most places; however, this practice has been questioned in an increasing number of countries due to animal welfare concerns ${ }^{(1)}$. The welfare implications of the act of castration are serious, in view of the acute pain induced by the procedure and the possible chronic pain or discomfort lasting from a few hours to days or weeks in some instances ${ }^{(2)}$.

The castration methods available are surgical with and without anesthesia, chemical, and immunological or immunocastration. Surgical castration without anesthesia is a method in which the skin is incised and the spermatic cords are pulled or the testicles "pulled out". Under commercial conditions, this management is performed in piglets less than seven days old, usually without anesthesia and analgesia. A second method is surgical castration with anesthesia and analgesia, which involves the use of local anesthesia before performing the surgical procedure, ligation of the vessels and analgesia after the end, to prevent pain in castrated piglets and adults. A third method is chemical castration, a temporary or definitive method of castration with the use of certain drugs or drugs injected directly into the testicle ${ }^{(3)}$.

Brazilian swine farms have grown significantly. Past swine rearing practices have made great strides in terms of production systems, producing genetic innovations and improvements in nutrition, sanitation, and management. Thus, it has become a swine production chain, which exploits the activity in an economic and competitive way ${ }^{(4)}$.

Moraes et al. ${ }^{(5)}$ and Ferreira ${ }^{(6)}$ teach that the meat of intact male pig has unpleasant odor and taste, which are not destroyed by heating or industrialization processes. Usually, the characteristic odor appears at puberty, around five months of age, and occurs due to the accumulation or association of compounds such as androsterone and escatol ${ }^{(7)}$.

In swine production, most of the animals destined for slaughter are castrated males. Surgical castration (orchiectomy) of young male pigs is a common procedure within swine production 
worldwide. It is estimated that around 100 million piglets are castrated annually, considering only the European Union countries ${ }^{(8)}$.

Castration reduces aggression and sexual activity, decreases testosterone levels, modifies carcass traits, decreases the number of animals with high muscle $\mathrm{pH}$ and provides control of undesirable mating. Non-castrated animals tend to produce lower quality, less consistent and with less marbling meat $^{(9)}$.

Thun et al. ${ }^{(10)}$ refer to the orchiectomy method as being more practiced, since it is a procedure with direct action on the testicles, preventing, thus, the production of spermatozoa and that of androsterone and testosterone. The choice of the surgical technique for orchiectomy in swine depends on factors inherent to each technique ${ }^{(11)}$.

Hemostasis is an important time during any surgical procedure. Methods for controlling surgical hemorrhage can be performed in small vessels by clamping, clamping and torsion, or by electrocoagulation. In medium and large size vessels, simple ligatures, transfixation, or coagulation by diathermy can be chosen ${ }^{(12)}$.

Several researchers ${ }^{(13-16)}$ demonstrated the use of nylon clamps (polyamide 6.6) for trans-surgical hemostasis. The nylon clamp, in addition to the traction resistant features, is an efficient locking system. The material is easy to handle and sterilize, low cost and well tolerated by the body ${ }^{(14)}$.

Silva et al. ${ }^{(15)}$ used nylon clamps as a form of preventive hemostasis in orchiectomies in cattle with satisfactory results. Used in orchiectomies in horses, they were subjectively evaluated and proved to be resistant to the traction exerted at the application site, and showed no signs of embrittlement. When compared to the use of the emasculator and the catheter, they presented a lower cost and reduced the duration of the procedure ${ }^{(14)}$. The device was used as a hemostatic method in ovary-hysterectomies in bitches by Lima et al. ${ }^{(13)}$. It was also used in ovary-hysterectomy preventive hemostasis in bitches $^{(17)}$ and cats ${ }^{(16)}$.

The aim of this study was to evaluate the operability and functionality of this device for the preliminary hemostasis of the spermatic cord in the open orchiectomy, comparing it to the surgical nylon thread.

\section{Material and Methods}

The study was carried out at the University of Rio Verde (UniRV) after the opinion N. 01/2016 of the Committee on Ethics in the Use of Animals (CEUA) of University of Rio Verde. Twenty 90-dayold male mixed race pigs, from rural properties in the city of Rio Verde, Goias state, underwent orchiectomy. They were randomly assigned to two groups of ten animals each for the surgical procedures. All the pre and postoperative procedures were identical and only varied in the form of ligature of the spermatic cords, as follows: Group I (GI) - ligation of spermatic cords with nylon clamp; Group II (GII) - ligation of spermatic cords with nylon thread.

For the animals of GI, colorless nylon (polyamide) clamps in the dimensions of $2.5 \mathrm{~mm}$ X $100 \mathrm{~mm}$ were used. They were sterilized in packages of three units per autoclaving system. Sterilized and 
needled nylon threads number 0 were used for GII, as suggested by Silva et al. ${ }^{(17)}$.

The mean weight of the animals was $20 \mathrm{~kg}$. They were submitted to pre-anesthetic medication consisting of Azaperone $(3 \mathrm{mg} / \mathrm{kg})$ and Midazolan $(0.5 \mathrm{mg} / \mathrm{kg})$ mixed in the same syringe and administered intramuscularly in the cervical region to generate less stress due to physical restraint. After 15 minutes, the animals were physically restrained and the infiltration of $2 \mathrm{~mL}$ of $2 \%$ lidocaine in the form of a longitudinal line into each testis (incision site) and $2 \mathrm{~mL}$ of intratesticular lidocaine was performed. Antisepsis was also performed with $2 \%$ iodopovidone.

Longitudinal incisions were made on each testicle through which they were externalized. The incisions in the scrotum were approximately $3 \mathrm{~cm}$ in length, depending on the size of the testicle. Additional tissue separation was performed to release each testicle from the surrounding tunic. The scrotal incisions were made as ventral as possible to facilitate the drainage of fluids from the wounds and reduce the risk of infections. The testes from de animals of GI were double ligated with nylon clamp (Figure 1). The ones from GII received a double ligation with 0 nylon thread (Figure 2) before being removed. The incisions were not sutured, to better drain the secretions. Penicillin benzathine $(10,000 \mathrm{IU} / \mathrm{kg})$ was given in a single dose. The surgical wound was cleaned with physiological solution and rifamycin was sprayed.

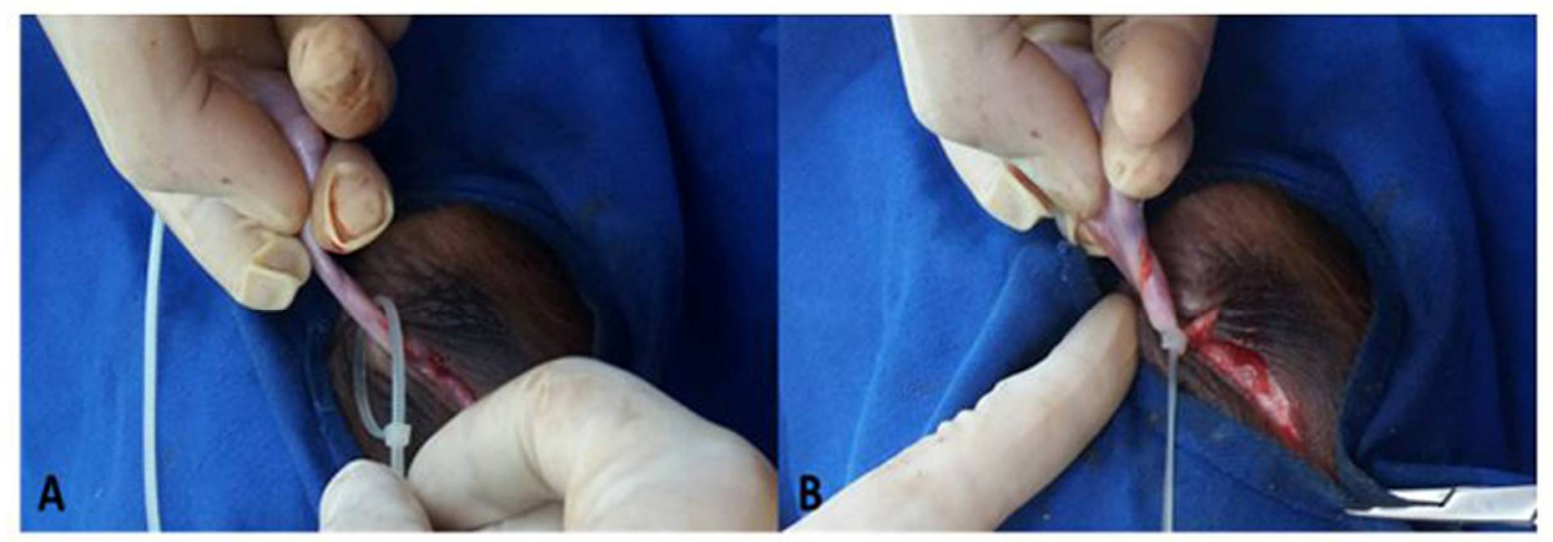

Figure 1 - Nylon clamp for orchiectomy in swine. (A) Positioning in the spermatic cord. (B) Braking system actuated.

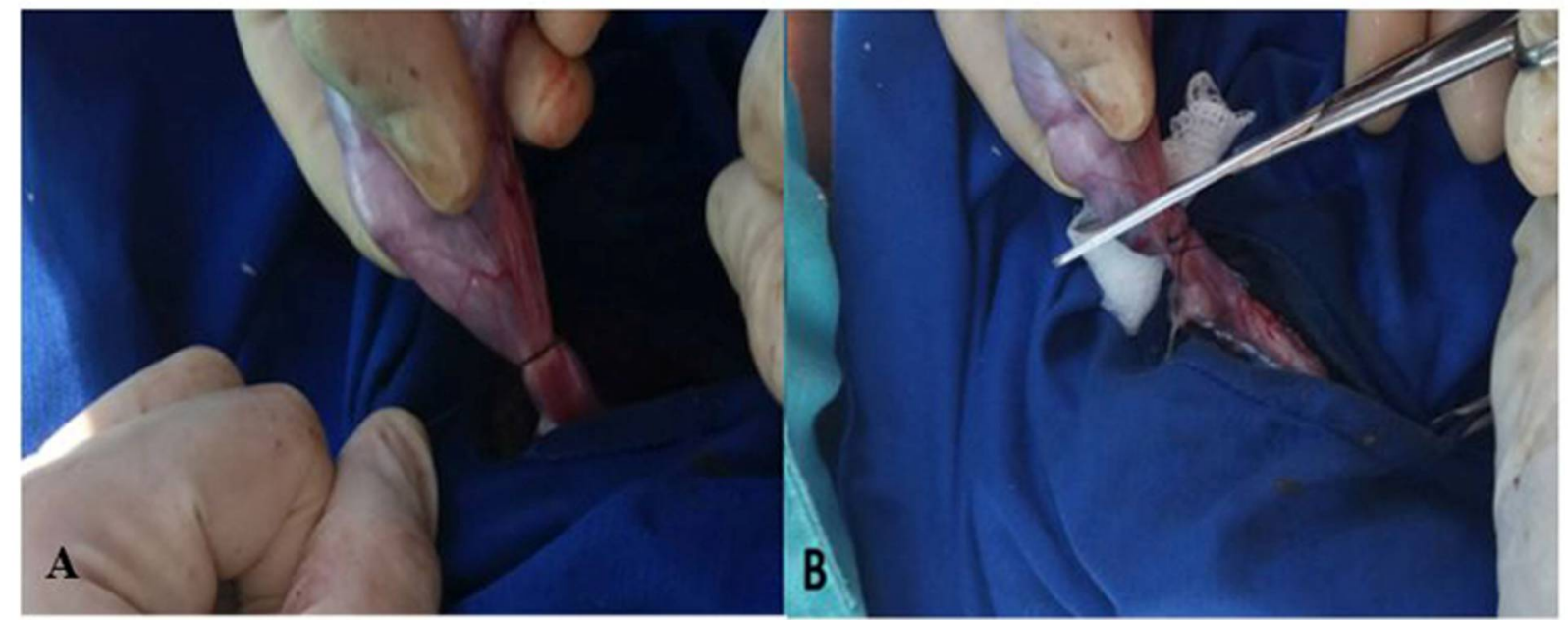

Figure 2 - Nylon thread for orchiectomy in swine. (A) Ligature with nylon thread. (B) Section of the spermatic cord.

The incision sizes were measured using a digital caliper. During surgery, the total procedure time for 
each animal was timed (surgical time, min). Bleeding was assessed by the volume of blood lost during the procedure. To do so, the blood volume was measured by weighing, in a precision scale, sterile gauzes used during surgery and, then, the blood volume loss (in grams) of each animal was registered ${ }^{(18)}$.

Surgical wounds were evaluated daily for seven days in relation to the presence of secretion (serous or purulent), edema and erythema. The day of complete healing of the surgical wound was also recorded. The fibrinogen levels were measured at the time of surgery and after seven days. For that, $3 \mathrm{ml}$ of blood was collected from the jugular vein of each animal on the day of the surgery and on the seventh day after it.

Fibrinogen concentration was determined by the classical method of heat precipitation, using a previously calibrated clinical refractometer (Portable Refractometer Model No. SZJ-D). Serum fibrinogen values were expressed as $\mathrm{mg} / \mathrm{dL}$ and the increase in fibrinogen levels after surgery were expressed as a percentage. The significant increase in the percentage of fibrinogen in one of the groups would indicate that there was a greater inflammatory response to the technique applied, possibly due to the hemostatic material used.

For the evaluation of the surgical times and hemorrhage degree between the groups, analysis of variance was complemented by $t$-test. For the non-parametric data, Mann Whitney test was used. For all the analyzes, $5 \%(\mathrm{p}<0.05)$ was set as the null hypothesis rejection level, and the highest significance values were marked with an asterisk.

\section{Results and Discussion}

The trans-operative evaluations involved the incision size, the blood loss, and orchiectomy procedure time (Table 1).

Table 1. Mean of incision size $(\mathrm{cm})$, blood loss $(\mathrm{mL})$, and total time of surgical procedure $(\mathrm{min})$ in pigs submitted to scrotal orchiectomy with different materials for ligation of spermatic cord

\begin{tabular}{lccc}
\hline \multicolumn{1}{c}{ Parameter } & $\begin{array}{c}\text { GI - } \\
\text { Nylon clamp }\end{array}$ & $\begin{array}{c}\text { GII - } \\
\text { Nylon thread }\end{array}$ & P \\
\hline Incision size $(\mathrm{cm})$ & 3.55 & 4.02 & 0.84 \\
Blood loss $(\mathrm{mL})$ & 0.81 & 1.9 & $0.002^{*}$ \\
Surgical time $(\mathrm{min})$ & 1.7 & 2.68 & $0.001^{*}$ \\
\hline
\end{tabular}

* Data analyzed using t-test.

There was no statistical difference regarding the incision size performed in both groups, but blood loss was more evident $(\mathrm{p}=0.002)$ in the group of animals submitted to nylon ligature (GII).

Prado et al. ${ }^{(16)}$ showed that the incision size may affect patient's recovery. Analysis of the size of the incisions between the groups shows that none of the techniques required an increase in the size of the incision.

Silva et al. ${ }^{(14)}$ and Costa Neto et al. ${ }^{(18)}$ found greater blood loss in the animals whose ligatures were performed with nylon thread. These authors have also demonstrated the importance of evaluating blood loss in surgical procedures. 
The hemorrhage level in orchiectomies performed in horses with pedicle ligatures with nylon clamp, single catheter, or emasculation has already been evaluated, and no difference between groups regarding blood loss has been noticed ${ }^{(14)}$. In our study with swine, there was more blood loss in orchiectomies performed with nylon thread, when compared to the nylon clamp, corroborating the results of a study conducted by Silva et al. ${ }^{(14)}$.

Another important observation evidenced in Table 1 refers to the time of surgery, which was notoriously superior $(p=0.001)$ in the group of swine that had ligatures with nylon clamp (GII). The evaluation of the total time of the surgical procedure is an extremely important parameter ${ }^{(16)}$. Several researchers have used the quantification of surgical time as a way of comparing techniques, such as Malm et al. ${ }^{(19)}$, who compared the procedure times of laparoscopic ovariay-hysterectomy and median laparotomy in bitches, and Prado et al. ${ }^{(16)}$, who also demonstrated the importance of checking the time spent performing surgical procedures involving felines.

Table 2 contains the values regarding the clinical changes observed in swine after orchiectomy.

Table 2. Formation of edema (number of animals) and day of complete healing (in days) observed in swine submitted to the scrotal orchiectomy procedure with different materials for ligation of the spermatic funiculus

\begin{tabular}{lccc}
\hline & $\begin{array}{c}\text { GI }- \\
\text { Nylon clamp }\end{array}$ & $\begin{array}{c}\text { GII - } \\
\text { Nylon thread }\end{array}$ & $P$ \\
\hline Presence of edema & $5 / 10$ & $7 / 10$ & 0.22 \\
Complete healing (days) & 8 & 8 & 0.22 \\
\hline
\end{tabular}

Mann Whitney test.

The data indicate that there was no difference between the number of animals that presented edema $(p=0.22)$ when compared by groups. They also indicate no difference between the groups on the day of complete healing of the surgical wounds. Changes like the presence of serous or even purulent secretions were not observed in any of the groups. No changes during daily physical examinations were recorded.

Silva et al. ${ }^{(14)}$ observed the presence of edema in orchiectomies in horses and noticed that this alteration happened in all groups to a greater or lesser degree. Finger et al. ${ }^{(20)}$ also evaluated the presence of alterations in orchiectomies performed in horses. Several animals from this experiment presented edema, but there was no significant difference between the groups, corroborating the findings of Silva et al. ${ }^{(14)}$ and Malm et al. ${ }^{(19)}$.

The weight gain between the groups after 30 days of surgery was recorded. Group I presented a mean weight gain of $60.76 \%$, while GII showed an average weight gain of $54.45 \%$. The $t$-test showed no significant difference between the groups $(p=0.17)$, indicating that none of the techniques influenced the animals' weight gain. Silva et al. ${ }^{(14)}$ wrote that weight gain is an extremely useful variable mainly for production animals.

The levels of fibrinogen were measured at the time of surgery and after seven days. The increase in these levels is set in Table 3 . 
Table 3. Percentage of animals with increased fibrinogen serum levels, observed in swine submitted to scrotal orchiectomy with different materials for ligation of spermatic funiculus, from the surgery moment up to the seventh day after it

\begin{tabular}{lccc}
\hline & $\begin{array}{c}\text { GI }- \\
\text { Nylon clamp }\end{array}$ & $\begin{array}{c}\text { GII - } \\
\text { Nylon thread }\end{array}$ & $\boldsymbol{P}$ \\
\hline Fibrinogen & $20 \%$ & $10 \%$ & 0.35 \\
\hline
\end{tabular}

Mann Whitney test.

According to the data displayed in Table 3, it is evident that there was no significant difference in fibrinogen levels $(\mathrm{p}=0.35)$ between GI and GII.

Fibrinogen is an acute phase protein synthesized by the liver, whose plasma concentration is elevated under the stimulatory action of interleukins (IL-1 and 6) and tissue necrosis factor released by the inflammatory process ${ }^{(21)}$. During the process of acute inflammation, the plasma concentration of this substance increases for several days, reaching a peak between the fifth and seventh day ${ }^{(22)}$. It does not suffer noticeable changes due to factors such as age, sex, exercise or hemorrhage, but can be affected by inflammatory processes ${ }^{(22,23)}$. According to Schalm et al. ${ }^{(22)}$, the degree of hyperfibrinogenemia may reflect the severity of the inflammation. The inflammatory reaction was not affected, regardless of the technique used.

\section{Conclusion}

The use of nylon clamps for hemostasis of the spermatic cords of swine submitted to orchiectomies reduced the total surgery time, as well as hemorrhages, when compared to hemostasis with nylon thread. Furthermore, weight gain and induction of inflammatory response were not influenced by the hemostasis method used.

\section{Acknowledgments}

Thanks to the University of Rio Verde (UniRV) for the grant awarded and for all support to the researchers who participated in this study.

\section{References}

1. Fredriksen B, Johnsen A M S, Skuterud E. Consumer attitudes towards castration of piglets and alternatives to surgical castration. Research in Veterinary Science. 2011;90:352-357.

2. Raulta JL, Lay Jr DCA, Marchant-Fordea JN. Castration induced pain in pigs and other livestock. Applied Animal Behaviour Science. 2011;135:214-225.

3. Teixeira F, Tocchet M. Manejos de maternidade na produção de suínos. In: Produção de suínos: teoria e prática. Brasília; 2014. p. 582-589. Portuguese.

4. Gonçalves RG, Palmeira EM. Observatório de la Economía Latino-americana: Suinocultura Brasileira. Rev. 
Académica de economia. [Internet]. 2006 Mês [2017 Jan 21]. Available from:http://www.eumed.net/cursecon/ecolat/br/. Portuguese.

5. Moraes N, Sobestiansky J, Wentz I. Manejo do leitão desde nascimento até o abate. In: Suinocultura intensiva: Produção, manejo e saúde do rebanho: Brasília; 1998. p. 135-162. Portuguese.

6. Ferreira RA. Suinocultura: Manual prático de criação: Viçosa; 2012. p. 433. Portuguese.

7. Martinuzzi PA, Viana AN, Kussler A, Cereser ND. Imunocastração em suínos. Seminario Interinstitucional de Ensino, Pesquisa e Extensão, 2011. p.16. Available from: https://www.unicruz.edu.br/seminario/artigos/saude/IMUNOCASTRA $\% \mathrm{C} 3 \% 87 \% \mathrm{C} 3 \% 83 \mathrm{O} \% 20 \mathrm{EM} \% 20 \mathrm{SU}$ \% $3 \% 8$ DNOS.pdf . Portuguese.

8. Soave GL, Trevisan C. Castração Alternativa em Suinocultura. Rev. eletrônica Nutritime. 2011;8(02): 1.461-1468.

9. AVMA - American Veterinary Medical Associations. Animal Welfare Division. Welfare implications of castrationo fcattle. 2009: 7p. Available from:

:http://www.avma.org/reference/backgrounders/castration_cattle_bgnd.pdf.

10. Thun R, Gajewsanki Z, Janett F. Castration in male pigs: techniques and animal welfare issues. Journal of physiology and pharma cology. 2006. 57:189-194.

11. Simplício RO, Caldara FR, Moi M, Santos LS, Santana MR, Panhosatto G. Alternativas de castração em suínos. VIII Simpósio de Ciências da UNESP: VIII Encontro de Zootecnia, Dracena. 2011. Available from: $<$ http://professor.pucgoias.edu.br/SiteDocente/admin/arquivosUpload/4753/material/Castra\%C3\%A7\%C3\% A3o\%20Cirurgica\%20e\%20Imunologica.pdf. Portuguese.

12. Lima AFDM, Luna SPL, Rodrigues MM, Quitzan J. Avaliação histológica e videolaparoscópica de ligaduras dos pedículos ovarianos realizados com mononáilon agulhado ou abraçadeiras auto-estáticas de náilon em cadelas submetidas à ovariossalpingohisterectomia pela técnica do gancho. Ars Veterinaria. 2010: 66-70.

13. Sorbello AA, Giudugli JN, Andretto R. Nova alternativa para ligaduras em cirurgias videoendoscópicas ou convencionais, com emprego de fitas de nylon em estudo experimental. Rev. Brasileira de Coloproctologia. 1999. 19(1):24-26.

14. Silva LAF, França, RO, Vieira D, de Sousa, VR, Franco LG, Moura MI, Bernardes KM. Emprego da abraçadeira de náilon na orquiectomia em eqüinos. Acta Scientiae Veterinariae. 2006.34(3):261-266.

15. Silva LAF, Borges NC, Ferreira JL, Cardoso LL. Orquiectomia em bovinos empregando abraçadeira de náilon na hemostasia preventiva: efeito da estação do ano, método de contenção e técnica cirúrgica. Ciência Animal Brasileira. 2009. 10(1):261-270.

16. Prado TD, Barboza S, Moni AF, Borges NC, Damasceno AD. Nylon clamps and mononylon for ovariohysterectomy in cats. Enciciclopédia Biosfera. 2015.11(21):1397-1411.

17. Silva LAF, Araújo GRS, Miranda AH, Rabelo, RE, Garcia AM, Silva OC, Oliveira KS. Ovariohisterectomia em cadelas: uso da abraçadeira de náilon na hemostasia preventiva. Ciência Animal Brasileira. 2004.5:100-102.

18. Costa Neto JM, Teixeira EM, Ferreira Filho EM, Toríbio JMML, Almeida Filho CHR, MoraesVJ. Braçadeiras de náilon para hemostasia preventiva na ovário-histerectomia em gatas. Revista Brasileira de Saúde e Produção Animal. 2009.10(3):15-624.

19. Malm C, Rocha PRS, Gheller VA, Oliveira HP, Lamounier AR, Foltynek V. Ovariohisterectomia: estudo experimental comparativo entre as abordagens laparoscópica e aberta na espécie canina - III. Estresse pela 
análise do cortisol plasmático. Arquivo Brasileiro de Medicina Veterinária e Zootecnia. 2005. 57:584-590.

20.Finger MA, Dornbusch PT, Bonfá AF,Dornbusch LPTC, Deconto I, Filho IRB. (2011) Comparação de duas técnicas de orquiectomia em equinos, empregadas no ensino da técnica cirúrgica veterinária. Archives of Veterinary Science. 2011. 16(3):53-59.

21. Vecina JF, Patrício RF, Ciarlini PC. Importância do fibrinogênio plasmático na identificação de processos inflamatórios de cães. Ciênc. vet. tróp. 2006. 9(1):31-35.

22. Schalm OW, Jain NC, Carrol EJ.Veterinary Hematology: Lea \& Febiger. 1975. p. 609. English.

23. Jain, N. C. Schalm`s veterinary hematology: Lea \& Febiger. 1986. p. 1221. English. 